\title{
Naprieč hranicami, mimo autentického a falošného: transnacionálna antropológia, turizmus a identita
}

\section{Across Boundaries, Beyond Authenticity and Falsity: Transnational Anthropology, Tourism and Identity}

Marek Mikuš

\begin{abstract}
The paper shows how two rarely linked fields of inquiry, transnational anthropology and tourism studies, can mutually enrich themselves. The overview of literature supports the view that, regarding the subject of transnationalism, social sciences have so far disproportionately focused on phenomena such as migration, diasporas and hybrid identities. Tourism, conceptualised as a globalised and globalising process par excellence, contrasts with these in that is constituted by national-boundary crossing not out of need, but in pursuit of pleasure and a desirable lifestyle. The author briefly outlines the two domains and then sets out to establish the relevance of their fusion in research on identity constructions and their relationship with place. He specifically elaborates the issues of , authenticity ' of emergent native ,tourist ethnicities ' and of the cultural capital that low-budget independent travellers (backpackers) allegedly generate by transnational mobility.
\end{abstract}

KEY WORDS backpackers, identity, place, tourism studies, tourist ethnicity, transnational anthropology

\section{Úvod}

Príbuzné témy transnacionalizmu a globalizácie sa v súčasnej sociálnej a kultúrnej antropológii a sociálnych vedách všeobecne stali rýchlo rastúcim pol'om záujmu. Zatial' čo pre prvú polovicu 90. rokov vyhl'adávanie výrazov „transnational“ a „transnationalism“ v abstraktoch a kl'účových slovách spoločensko-vedných štúdií evidovaných databázou SocINDEX prinieslo 380 výsledkov, pre druhú polovicu 90. rokov to bolo už 844 textov a pre roky 2000-2005 dokonca 3083 prác (EBSCOhost 2008). Podobné výsledky sú dokumentované pre kl'účové slovo „globalization“ v prípade sociologických štúdií (Gille a Ó Riain 2002: 272). Takýto strmý kvantitatívny nárast je nepochybne dôkazom meniacej sa povahy antropologických objektov - kultúry a spoločnosti - a snahy disciplíny postihnút' tieto procesy vo svojej teórii a metóde.

Sociální studia. Fakulta sociálních studií Masarykovy univerzity, 1/2009. S. 187-210. ISSN 1214-813X. 
V tejto stati sa túto novú, rodiacu sa antropologickú paradigmu pokúšam formou analýzy literatúry systematicky prepojit' s výskumom turizmu a demonštrovat' potenciálne obohatenie plynúce z takého spojenia pre obe domény; súčasne ide o úvodný, prehl'adový príspevok k téme, na ktorú slovenská a česká sociálna veda zatial' nereflektovala. Je dôležité podotknút', že turizmus síce už bol rozpoznaný ako dôležitá oblast' bádania pre transnacionálnu antropológiu, ale jej špecifická analytická optika bola naň aplikovaná len sporadicky; v opačnej perspektíve sa zase dá konštatovat', že niektoré teoretizácie transnacionalizmu sa ani nepokúšali o inklúziu relevantných empirických zistení turistických štúdií a obmedzili sa na predmety ako migrácia či diaspóry. Jedným z najsl’ubnejších presahov medzi týmito dvomi doménami sa zdá byt' téma identity a jej vzt'ahu s (geografickým a sociálnym) priestorom, ktorá navyše bola vo vzt’ahu k turizmu rovnako ako transnacionalizmu sociálnymi vedcami pomerne intenzívne skúmaná a rozpracovaná. V nadväznosti na povahu interakcií medzi priestorom a spoločnost'ou $\mathrm{v}$ globalizujúcom sa svete (viz nižšie) je pritom možné rozlíšit' roly turizmu na faktor vzniku transnacionálnych identít na jednej strane a transnacionálne médium vzniku lokalizovaných identít na strane druhej. Tieto fenomény konkrétne ilustrujem na dvoch prominentných predmetoch záujmu: na turizmom podnietenej (re)konštrukcii „domorodých“identít a etnických vzt’ahov a na naratívnej sebaprezentácii nezávislých či nízkonákladových turistov, ktorých anglické označenie backpackers $\mathrm{v}$ tomto texte prekladám slovenským neologizmom batôžkári.

\section{Transnacionálna antropológia: toky, miesta a translokality}

Povojnová sociálna veda sa domnievala, okrem iného v súlade so spôsobom regulácie svetovej ekonomiky, že národný štát predstavuje akúsi „nádobu“ pre sociálne, ekonomické a politické procesy prebiehajúce na jeho území, a že všetky javy, ktoré tento rámec presahujú, by sa mali posudzovat' ako oblast' „medzinárodných vzt’ahov“. Podobne klasický výskumný predmet antropológie predstavovali lokalizované „kultúry“ či „komunity“ - bola to práve predstava diskontinuity a hlbokých predelov medzi priestormi zodpovedajúcimi jednotlivým kultúram, všetkým pevne a objektívne zasadeným a ukotveným „,na svojich miestach“, ktorá umožnila predpokladat’ typ rozdielnosti a autonómie kultúr symbolizovaný napr. etnografickými mapami, podporujúcimi substantizáciu a reifikáciu etnicity (Bazin 2002: 23). Základný mechanizmus vedeckého („objektívneho“) a politického diskurzívneho vymedzovania regionálnej identity sa teda zásadne nelíšil (Bourdieu 1992). Tomuto konceptuálnemu východisku zodpovedal dôraz na lokalizovaný charakter kl'účovej antropologickej metódy - etnografie. Legitimita antropológovho vedenia o určitej skupine l'udí sa odvodzovala od toho, že po dostatočne dlhú dobu žil „medzi“ nimi, pozoroval ich a podl’a možností sa zúčastňoval ich každodenného života (,participatívne pozorovanie“), čo mu umožnilo vyprodukovat’ o nich strategickú textuálnu zmes objektivizovaného popisu a osobnej narácie, ktorá prezrádzala príznačnú spriaznenost's cestovatel'skou literatúrou (Pratt 1986).

Ako ukazuje antropologická kritika inšpirovaná postmodernou a feministickou teóriou, táto konvenčná perspektíva bola vo svojej podstate epistemologicky problematická a neuspokojivá vždy (Gupta a Ferguson 1992), ale v ére globalizácie sa javí ešte menej udržatel'ná ako kedykol'vek predtým. L’udia, kapitál, tovary, práca, ale najmä diskurzy, znaky a kultúrne 
prvky sa vd’aka rozvoju a rozširujúcej sa dostupnosti dopravy a informačných a komunikačných technológií stávajú stále mobilnejšimi a mnohonásobne, komplikovane trans-lokálne prepojenými, čím prispievajú $\mathrm{k}$ rušeniu alebo zmene postavenia hraníc umožňujúcich konštrukciu prísne oddelených a fundamentálne odlišných sociálnych priestorov. Proces deteritorializácie posilňuje vedomie, že „skupiny už nie sú pevne teritorializované, priestorovo ohraničené, historicky nevedomé či kultúrne homogénne“ (Appadurai 1991: 191), a preto ani skúmatel'né tradičnou etnografiou. Pozornost' antropológov ako Appadurai, ale aj kultúrnych teoretikov ako Hall (1991), si získali rozmanité hybridné a diasporické identity migrantov a obyvatel'ov prihraničných oblastí a takisto „nové etnicity“, ktoré pre seba transnacionálna mládež synkretizuje z vedome zvolených prvkov rôznych kultúrnych dedičstiev. Vel'kou čast'ou bývalej ekonomickej a politickej moci národných štátov dnes disponujú nadnárodné spoločnosti (v tomto kontexte označované aj ako transnational corporations, TNCs) a predstavujú tak nové (niekedy len zdanlivo), deteritorializované a voči verejnosti slabo zodpovedné ohniská rozhodovacích procesov. ${ }^{1}$

$\mathrm{Na}$ tieto vývinové tendencie reaguje antropológia transnacionalizmu, budovaná predovšetkým od začiatku 90. rokov okolo konceptu rozmanitých typov prekračovania hraníc, ktorý môžeme v súlade s užitočnou Vertovcovou analýzou (1999) rozdelit' na nasledujúce zložky: transnacionalizmus ako sociálna morfológia, typ vedomia, spôsob kultúrnej reprodukcie, operácie kapitálu, priestor politickej angažovanosti a rekonštrukcia miesta či lokality. Špecifický prínos tej podoby transnacionálnej antropológie, ${ }^{2}$ ktorá je $\mathrm{v}$ tejto štúdii stavaná do popredia, a takisto jej odlišnost' od niektorých teórí globalizácie, spočíva najmä v dôkladnom skúmaní identitárnej (re)produkcie a v snahe o adekvátne historické postihnutie meniacej sa role národa a národných štátov či, $\mathrm{v}$ širšom pohl'ade, miesta ako takého $\mathrm{v}$ zdanlivo odtelesnených podmienkach „tekutej modernity“ (Bauman 2002). Inými slovami - pozornost' venuje nielen tokom (Hannerz 1997: 4-6) či sietiam, ktoré prúdia medzi jednotlivými pozíciami a spájajú ich, ale aj sociálnym rekonštrukciám miest a komunít spolu s ich dialektickými vzt’ahmi ku globálnemu a medzi sebou navzájom. Reflektuje teda rovnako „priestor tokov“ ako „priestor miest“, na ktorý je aplikovaný a v istom zmysle ho hegemonizuje (Castells 1996), a snaží sa túto jednoduchú dichotómiu prekročit’ rozpohybovaním miesta, jeho rekonceptualizáciou ako fluidného samého o sebe a prostredníctvom sociálnej imaginácie v rozdielnych geografických meradlách dynamicky prepojeného so svojím vonkajškom.

Tieto procesy viedli Urryho (2000: 11) až k spochybneniu ontologického statusu základného sociologického pojmu ,spoločnosti“, podl'a neho odvodeného a z vel'kej časti synonymného s historicky špecifickou sociálnou formou národného štátu, ktorá vznikla na priemyselne-kapitalistickom Západe v 18.-19. storočí.

2 Pre účely tejto práce, ktorá prehovára skôr z pozície „transnacionálnej antropológie“ než ,,antropológie transnacionalizmu“, je užitočné navrhnút' významové odlíšenie týchto dvoch označení. Kým antropológia transnacionalizmu sa zdá akcentovat’ antropologický výskum transnacionalizmu ako reálneho či analyticky vyčlenitel'ného objektu, transnacionálna antropológia používa opti$k u$ spresnenú konceptuálnym modelom transnacionalizmu pri komplexnom pohl'ade na celý rad sociálnych javov a procesov v súčasnom globalizujúcom sa svete. Toto epistemické, ,adjektívne“ poňatie subdisciplíny umožňuje vyvarovat' sa stotožnenia trasnacionalizmu s akousi substanciou a vo vzt’ahu k výskumu turizmu je logickou vol'bou. 
Upozorňuje tiež na to, že významná čast’ zdrojov a moci zostáva viazaná na konkrétnych miestach a že prístup jednotlivcov k mobilite môže byt' výrazne odlišný v závislosti na ich príslušnostiach ako občianstvo, trieda, „rasa“, etnicita, rod či socioekonomický status (cf. Bauman 1999). Súčasne v súlade s interpretatívnou, na porozumenie zameranou povahou disciplíny ako takej hl'adá odpovede na otázky o tom, ako vplýva konanie (agency) rôznych sociálnych aktérov, rovnako ako štruktúra ich vzájomných mocenských pozícií, na procesy vytvárania miest, a akým spôsobom tieto procesy spätne formujú konštrukciu identít. Tým sa vyhýba nebezpečenstvu technologického determinizmu (Vertovec 2001: 577), rovnako ako slabinám „kulturalistických“ prístupov, ktoré abstrahujú globálne prúdenie znakov a symbolov od mocenských štruktúr, v ktorých sú zasadené.

Ako už bolo naznačené vyššie, transnacionálnu antropológiu je potrebné vnímat' na jednej strane v súvislosti s celkovým príklonom k praxi, procesu a pohybu v súčasnej antropológii (Ortner 1984) a na druhej strane v kontexte rodiacej sa makroantropológie, označovanej tiež ako globálna či kozmopolitná antropológia. Napríklad James Clifford vo svojej vplyvnej práci (1997) zdôrazňuje nutnost' antropológie nahliadat' kultúry nie ako homogénne, lokálne a statické entity, ale ako procesy stretávania sa a výmeny medzi l'ud'mi, ktorí cestujú, a tiež tými, ktorí zostávajú doma. Namiesto „umiestňovania“ kultúr (placing of cultures) je nutné nechat’ kultúry diat' sa (take place) na ich aktuálnych fyzických miestach: „antropologická ,kultúra' už nie je tým, čím bývala. A ked' rozoznáme, že výzva pre reprezentáciu spočíva v zobrazovaní (...) historických stretnutí lokálneho a globálneho (...) je potrebné sústredit’ sa rovnako na hybridné a kozmopolitné skúsenosti ako na tie zakorenené a domorodé. Ciel'om tejto mojej problematizácie nie je nahradit' kultúrnu postavu ,domorodca interkultúrnou postavou ,cestovatel'a‘. Úlohou je skôr zamerat' sa na ich konkrétne sprostredkovania“ (ibid.: 24), pričom jedným z médií týchto neustále obnovovaných kontaktov je podl'a Clifforda aj turizmus.

Vnímaná geografická blízkost’ nevymedzovala len identity objektov klasickej antropológie - je tiež jedným z možných kognitívnych predpokladov procesov skupinovej identifikácie a sociálnej kategorizácie (Jenkins 1996). V súlade s Appaduraiom (1995) môžeme rozlíšit' medzi locality (miesto, umiestnenie) ako fenomenologickou kvalitou, hodnotou či ideológiou lokálnej skupiny, a neighbourhood (komunitou) ako sociálnou formou, definovanou priestorovou či virtuálnou realizáciou miesta a potenciálom pre sociálnu reprodukciu. Komunita figuruje ako nevyhnutný kontext produkcie lokálnych subjektov a zmysluplných l'udských praktík, ale súčasne sama kontext generuje a vyžaduje pre svoju konštrukciu a udržanie. Táto neprestajná hra kontextu a komunity podmieňuje pragmatickú a diskurzívnu konštrukciu nevyhnutne ne-lokálnych, globálnych typov vedomia označovaných ako „krajiny etnicity“ (ethnoscapes), ${ }^{3} \mathrm{~s}$ ktorými sú miestne identity a praktiky kontrastované ako rozdielne. V čase

Podl'a Appaduraia (1991: 198-199) majú vd’aka informačným technológiám dnes l’udia, dokonca aj tí žijúci v najtvrdších podmienkach, prístup k obrovskému množstvu semiotického materiálu, ktorý im umožňuje predstavovat' si svoj život celkom inak a tým ho prípadne modifikovat'. Táto „imaginácia možných životov“ je kultúrnou praktikou, ktorá leží v jadre konceptualizácie dialektiky globálneho a lokálneho, a skladá sa z piatich dimenzií globálneho kultúrneho toku: krajín etnicity (ethnoscapes), médií (mediascapes), financií (financescapes), technológií (technoscapes) a ideí 
destabilizácie národných projektov je pritom produkcia miesta čoraz náročnejšia vzhl’adom na vytrácajúcu sa súvislost' jednak medzi teritóriom a subjektívnymi a kolektívnymi identitami (deteritorializácia) a jednak medzi priestorovo vymedzenými a virtuálnymi (napr. elektronicky mediovanými) komunitami.

Výsledkom je na úrovni konštrukcie miest vznik translokalít ako určitých „plurálnych“, viacnásobne a často viacúrovňovo definovaných miest. Ich príkladom sú aj frekventované turistické lokality - fakt, že ležia na území národného štátu, je v nich ako kontextuálny faktor oslabený v prospech spojení a vzt’ahov, ktoré štát evidentne presahujú. V podobnom duchu Bruner (1996) označuje popredné turistické oblasti, napr. Bali, ako „turistické hraničné zóny“ (viz nižšie). Na úrovni sociálnej morfológie a zodpovedajúcich druhov (skupinového i individuálneho) vedomia a identít potom praktiky udržiavania spojenia a prekračovania hraníc medzi viacerými miestami konštituujú transnacionálne sociálne polia. Tieto sa rozprestierajú medzi jednotlivými „prostrediami významov“ (Hannerz 1996), ktoré nesú odlišnú semiotickú zát'až podmieňujúcu formáciu identity - „dejiny a stereotypy miestnej prináležitosti a vylúčenia, geografie kultúrnych rozdielov a triednej či etnickej segregácie, rasizované (racialized) socioekonomické hierarchie, stupeň a druh kolektívnej mobilizácie, prístup k zdrojom a ich povaha, a obmedzenia a spôsoby vnímania práv a povinností“ (Vertovec 2001: 578).

Pre úplnost' je treba podotknút', že čast' autorov pôsobiacich $\mathrm{v}$ transnacionálnych štúdiách sa vedome snaží obmedzit' svoju oblast' záujmu len na to, čo pre nich predstavuje historicky nové sociálne vzt’ahy umiestnené kdesi medzi národnou a globálnou úrovňou konkrétne dlhodobé a pravidelné aktivity migrantov, transnacionálnych podnikatel'ov a d’alších vysídleneckých skupín uskutočňované cez národné hranice (Portes et al. 1999). Zrejmý je dôraz na sociálne správanie $\mathrm{v}$ transnacionálnych ekonomických, politických a sociokultúrnych ${ }^{4}$ doménach na úkor symbolického a kognitívneho rozmeru. $\mathrm{Z}$ logiky tohto zamerania potom vyplýva vylúčenie príležitostných kontaktov, ktoré síce „tiež prispievajú k posilneniu transnacionálneho pol'a, ale samy o sebe nie sú ani nové, ani dostatočne odlišné, aby ospravedlnili novú oblast' záujmu“ (ibid.: 219).

Ohliadnuc od toho, že sa tým zanedbáva historický náhl’ad dopadu novej del'by práce medzi jednotlivými úrovňami (globálnou, národnou, lokálnou) na premenu jednotlivých oblastí činnosti (Gille a Ó Riain 2002: 275), sa v tejto práci pokúšam demonštrovat', že zvýšenú pozornost' si rovnako zasluhujú aj mentálne a sociolingvistické fenomény. Transnacionálne diskurzy o identite (Benwell a Stokoe 2006) v kontexte turizmu svojím stále rastúcim významom pre každodenný život a seba-identifikáciu turistov, príslušníkov hostitel'ských spoločností a d'alších účastníkov turistických transakcií dostatočne zdôvodňujú

a ideológií (ideascapes). (Zložka -scapes bola preložená do slovenčiny in Mattová 2007: 51 ako „obrazy o [médiách atd'.]“. Tu postupujem odlišne a vzhl’adom na zamýšl’anú pôvodnú asociáciu s pohl'adom na krajinu z určitého bodu - landscape - používam výraz „krajina“). Ethnoscapes Appadurai (1991: 192) popisuje ako „krajiny l'udí, ktorí vytvárajú premenlivý svet, v ktorom žijeme: turistov, imigrantov, utečencov, exulantov, zahraničných pracovníkov, a d’alších mobilných skupín a osôb".

$4 \quad$ Z enumerácie relevantných aktivít v sociokultúrnej oblasti (Portes et al. 1999: 222) je pritom evidentné skôr axiologické chápanie kultúry ako jej použitie v zmysle analytického antropologického modelu. 
ustanovenie nového výskumného pol’a. Rovnako ako je transnacionalizmus uplatňovaný ako analytická optika v interdisciplinárnom výskume súčasnej medzinárodnej pracovnej migrácie (Vertovec 2001: 574), je jeho aplikácia možná aj v antropologickom pohl'ade na turizmus. Nakoniec, konzumná prít’ǎlivost' vel'kej časti turistických produktov (najmä tzv. „etnického“ či „kultúrneho“ turizmu) spočíva práve v transnacionálnej mobilite - v prekračovaní geografických a symbolických hraníc a kontakte s Inými, čiže situácii konfrontácie, ktorá je klúčcová pre výskum tradičného antropologického predmetu - vytvárania etnických hraníc (napr. Barth 1998, Bauman 1996: 41-56). Bez semiotiky hraníc by kultúrny turizmus prišiel o svoje čaro - ved' migranti z tretieho sveta žijú vo vel'kých počtoch aj v západných spoločnostiach (teda „medzi Nami“), z ktorých tento druh medzinárodných turistov zväčša pochádza, ale predmetom záujmu sa stávajú iba na miestach, ktoré spoluvytvárajú žiaduci dojem ich primordiálnej a statickej odlišnosti (Bruner 1996: 160). Prepojenie domén turizmu a transnacionalizmu nie je len možné, ale i potenciálne prospešné, pretože pochopenie zvláštností produkcie identít súvisiacich s turizmom (napr. „komodifikácia kultúry“ a prekračovanie hraníc v kontexte spotreby a životného štýlu) sl’ubuje významné prehíbenie teórie transnacionálnych sociálnych foriem a typov vedomia, ktorá sa doposial' sústredila najmä na problematiku migrácie a diaspór.

\section{Spoločensko-vedná reflexia turizmu}

Logickost' prepojenia týchto dvoch oblastí silne podporuje aj skutočnost', že typické znaky globalizácie, ako „[t]lak na skrátenie doby obratu medzi investovaním a vytváraním zisku, kompresia času, posun od výroby $\mathrm{k}$ službám, miešanie a vynachádzanie tradícii a zvýšená produkcia a spotreba simulakier sa všetky stretávajú v najväčšom svetovom priemysle turizme“ (Kearney 1995: 555). K tomu by d’alej bolo možné na ekonomickej úrovni pridat' aj „neo-fordistickú“ organizáciu tohto odvetvia a významnú rolu, ktorú v ňom hrajú transnacionálne spoločnosti (Bianchi 2000: 115-117). Vzt’ah turizmu ku globalizácii je recipročný je jedným z jej médií a súčasne epifenoménov, ked’že jeho rast je stimulovaný rozvojom transportu a informačných technológií, deregularizáciou svetovej kapitalistickej ekonomiky, tlakom na zvyšovanie flexibility práce a d’alšími charakteristickými globalizačnými trendmi. Turizmus je vysoko relevantný tiež vzhl'adom na skutočnost', že predstavuje najväčšie odvetvie $\mathrm{v}$ sektore služieb a s vysokou pravdepodobnost'ou vôbec najčastejšiu podobu dnešnej l'udskej mobility - Svetová turistická organizácia (UNWTO) hlási, že v roku 2006 bolo $51 \%$ z 846 miliónov medzinárodných príchodov motivovaných vol'nočasovými aktivitami, rekreáciou a prázdninami (UNWTO 2007).

Navyše v súlade s postmoderným rušením hraníc medzi vysokými a nízkymi kultúrami a jednotlivými druhmi kultúrnych a spoločenských činností dochádza i $\mathrm{k}$ „dediferenciácii“ turizmu. „Nielenže je rozdiel medzi turizmom a d’alšími aspektmi kultúry čoraz nejasnejší, ale turistické spôsoby inscenovania, vizualizácie a vnímania sa stávajú čoraz dôležitejšími pre iné oblasti spoločenského života“ (Wood 1998: 229). Vznik unifikovaných a komercializovaných tematických prostredí, simulakier (Baudrillard 1995), ktoré nahrádzajú prostredia rozprávajúce lineárne „príbehy“ charakteristické pre modernitu (Gottdiener 2001), je evidentný nielen v priestorovo separovaných Disneylandoch a iných zábavných a náučných 
parkoch, ale i v súčasných vel'komestách, ktoré ich obyvatelia vd'aka tomuto trendu čoraz častejšie zakúšajú kvázi-turistickým spôsobom. Shellerová a Urry (2004: 5) v úvode k zborníku prípadových štúdií o turistických mobilitách a miestach konštatujú, „,̌e čoraz menej ,turizmu' sa odohráva vo vel'mi odlišných druhoch časopriestoru; nastáva ,koniec turizmu“ per se v rámci všeobecnej, ekonómie znakov`. Turistické lokality sa množia po celej planéte, zatial' čo miesta každodennej aktivity dostávajú novú ,turistickú formu, ako je tomu s tematizovanými nákupnými, vol’nočasovými a pracovnými prostrediami.“

Takisto etnická či národná identita je čoraz častejšie prežívaná a konštruovaná v takýchto prostrediach. Mladé, kultúrne a etnicky vysoko heterogénne štáty sa tak môžu snažit' utvárat' „správne“ národné vedomie budovaním príslušným spôsobom štruktúrovaných etnických tematických parkov, ako na príklade Taman Mini na Jáve ukazuje z antropologického pohl’adu Hitchcock (1998). Pri výstavbe tohto múzejného a exhibičného komplexu, ktorý je určený primárne domácim návštevníkom, vyšiel Suhartov „New Order“ režim z oficiálnej doktríny indonézskej ,jednoty v suverenite“ a cielene v ňom zdôraznil vybrané „regionálne kultúry“ na úkor rozdielnych etnicít. Takéto priestory pritom nemusia nevyhnutne vnucovat' uniformizovanú verziu identity, ako sa v nadväznosti na teórie Frankfurtskej školy často predpokladá; napr. mladí austrálski „pracujúci dovolenkári“ v Londýne svoju identitu pri návštevách stereotypne štylizovaných austrálskych barov, ktoré spadajú pod generické ret’azce, aktívne reflektujú, prehodnocujú a vyjednávajú o nej (West 2006). Ďalej treba zmienit', že turizmus nie je len motiváciou pre klasickú medzinárodnú pracovnú migráciu (King 1995, Williams, Hall et al. 2002), ale tvorí aj zložku hybridných foriem mobility spájajúcich turizmus so zamestnaním. Vychádzajúc z etnografických výskumoch na Malorke a Kanárskych ostrovoch, prirovnáva Bianchi (2000) situáciu transnacionálnej západnej mládeže, ktorá čast' svojich dlhodobých pobytov v turisticky exponovaných častiach Stredomoria pracuje a čast' odpočíva, prípadne úspešne integruje rekreáciu so svojimi pracovnými záväzkami, k novodobému trampingu a spája ju s reštrukturalizáciou kapitálu v post-industriálnych zdrojových krajinách ako dôležitým push faktorom. Ďalším dediferenciačným trendom je čoraz častejšie kombinovanie turistiky so športom, dobrovol’níctvom, záujmovými a vzdelávacími aktivitami, často smerujúcimi k osobnostnému rastu, ako je tomu napríklad v prípade ekoturistov (Duffy 2004). ${ }^{5}$

Hoci mojím ciel’om nie je ani v najmenšom podat' vyčerpávajúci prehl'ad existujúcej spoločensko-vednej, najmä antropologickej literatúry o turizme (pozri prehl'ad sociológie turizmu v tomto zborníku in Chorvát 2006), v nasledujúcich pasážach sa pokúsim stručne charakterizovat' klúčcové trendy a témy výskumu, predovšetkým tie s presahmi k špecifickému predmetu tejto práce - súboru vzt’ahov medzi turizmom, priestorom a identitou.

5 Výsledkom týchto procesov je okrem iného aj to, že snaha „objektívne“ vymedzit’ turizmus ako empirický jav naráža na čoraz väčšie problémy. Len t’ažko dnes môžeme vnímat' definíciu, podl’a ktorej turista je človek cestujúci mimo domova za účelom trávenia vol’ného času a zážitku prechodnej zmeny (Nash 1981: 462), ako dostatočne inkluzívnu pre všetky popísané formy turizmu. Navrhujem preto ako užitočnejšie pristupovat' k takémuto ohraničeniu turistu nie ako k objektívnej deskripcii, ale ako k sociálne konštruovanému l’udovému modelu, ku ktorému sa jednotliví účastníci turizmu rozmanitými spôsobmi vzt’ahujú. 
Napriek evidentnému významu turizmu pre tradičné antropologické oblasti záujmu ho disciplína začala vo väčšej miere reflektovat' pomerne neskoro - autori sa viac-menej zhodujú na datovaní počiatkov antropológie turizmu do 60.-70. rokov (Bianchi 2003: 14-15, Shepherd 2002: 196, p. 2, Stronza 2001: 263-264). Príčiny tejto dlho pretrvávajúcej ignorancie by si zrejme zasluhovali dôkladnejšie preskúmanie, než poskytujú všeobecné odkazy na asociácie turizmu s frivolnost'ou a plytkost'ou (napr. Nash 1981: 461); rolu mohla zohrat' napríklad snaha antropológov čo najviac sa dištancovat' od turistov ako svojho neseriózneho a laického temného odrazu, s ktorým ich domorodci napriek tomu bez pocitov viny neraz zamieňali a zarad'ovali do spoločnej kategórie. Kl'účová však nepochybne bola jedna z dnes prekonávaných, hodnotovo zat’ažených konceptuálnych dichotómií, ktorej sa bližšie venujem nižšie protiklad ,autentickej“ a „falošnej“ kultúry.

Výsledkom neskorého nástupu systematického antropologického bádania je, že ešte pred dvanástimi rokmi Nash (1996: 15) vo významnej syntetickej publikácii upozorňoval na teoretickú nedostatočnost' tohto pol’a, nahrádzanú moralizovaním a prostou popisnost'ou. Bližšie k súčasnosti Stronzová (2001: 263) konštatuje, že v teoretizujúcej literatúre o motiváciách turistov chýba uspokojujúca empirická báza, zatial' čo publikácie o dopadoch turizmu sa spoliehajú na dáta bez toho, aby ich analyzovali a konceptualizovali. Ešte slabšie rozoznávajú turizmus ako zásadnú tému autori v oblasti transnacionálnej antropológie - názorne o tom vypovedá napr. fakt, že v prehladovej stati Stevena Vertovca (1999), vtedajšieho i súčasného riaditela výskumného programu britskej Rady pre ekonomický a sociálny výskum (Economic and Social Research Council) „Transnational Communities“, absentuje akákol'vek zmienka o turizme, a to aj napriek tomu, že je tu v stručnosti predstavený spomínaný program a jednotlivé jeho tematické okruhy. Čiastočným vysvetlením môže byt práve explicitná orientácia na (analyticky otáznu) kategóriu „komunity“, ktorá je nekompatibilná so skúmaním niektorých druhov skupín a identít súvisiacich s turizmom. Tie sa totiž vzpierajú dvom klasickým spôsobom vymedzenia etnografického objektu, ktorými sú jednak zdiel’anie lokality u sedentárnych skupín a potom „kohézna sociálna interakcia v rámci jasne ohraničenej skupiny s obmedzenou výmenou jedincov" v prípade nomádov (Sørensen 2003: 850). $\mathrm{S}$ týmto druhom teoretickej a metodologickej výzvy by sa ale transnacionálna antropológia mala dokázat' vysporiadat'.

Ďalšou dichotómiou príznačnou pre staršie spoločensko-vedné práce o turizme predstavovalo striktné rozdelenie jeho účastníkov na dve funkčne viazané jednotky, „turistov“ a „hostitel'ov“ (napr. Smith et al. 1989, Mathieson a Wall 1982), pričom rola tých druhých bola typicky nahliadaná ako pasívna (cf. príznačnú dvojicu tvarov používaných van den Berghem tourist vs. touree). Príslušníkom hostitel'ských spoločností bol turizmus nanútený, oni sami sa na jeho prilákaní aktívne nepodiel'ali a neboli schopní ovplyvnit' a negociovat' jeho konkrétne charakteristiky. Podl'a Aramberriho (2001: 756-757) koncepcia vzt'ahu host'-hostitel' založeného na nehmotnej reciprocite, ktorú zaviedli antropológovia a neskôr uplatňovali najmä marxisticky orientovaní kritici, je anachronická, pretože „,neumožňuje objasnit' domáci turizmus ani medzinárodné príchody do vyspelých destinácií, teda drvivú väčšinu turistických transakcií. V skutočnosti dokonca aj $\mathrm{v}$ malých komunitách utilitárna väzba zákazníci-prostredníci-poskytovatelia nahradila dohodu, ktorá v minulosti vymedzovala vzt’ah host’a a hostitel'a." Ďalší závažný prúd kritiky odmieta, že by turizmus mohol 
byt’ chápaný ako „vonkajší“ vo vzt’ahu k miestnym kultúram a spoločnostiam (viz nižšie). Poukázat' sa tiež dá na empirické prípady vybočujúce z tejto jednoduchej klasifikácie, akými sú napríklad pracujúci turisti (Bianchi 2000, West 2006), z ktorých mnohí hladajú prácu $\mathrm{v}$ turistickom sektore.

Antropológovia predpokladajúci polaritu hostí a hostitel'ov sa vo vzt’ahu k vplyvom turizmu zameriavali prevažne na pochopenie toho, čo znamená pre miestne komunity; príčiny a motivácie zase vysvetl'ovali takmer výhradne z pohl'adu turistov, ${ }^{6}$ pričom neskúmali, akými zmenami prechádzali - „zdá sa, že oba prístupy, dokonca aj ked' sú skombinované, hovoria len polovicu príbehu“ (Stronza 2001: 262). Ak dáme bokom zdanlivo hodnotovo neutrálne práce obmedzené na pragmatické riešenie problémov spojených s rozvojom turizmu, v starších kritických prácach vo všeobecnosti prevažoval pri vysvetl'ovaní vzt'ahov medzi zdrojovými a host’ovskými spoločnost’ami skôr doraz na štrukturálnu determináciu než konanie aktérov. Boli to práve tieto neokolonialisticky a esencialisticky orientované práce, ktoré často zanedbávali samostatné konanie príslušníkov miestnych „komunít“ (neraz zobrazovaných ako statické a pevne ohraničené) a snažili sa ukázat', že turizmus prispieva k vytváraniu „závislostí“ medzi metropolitnými (t. j. zdrojovými) a periférnymi (t. j. ciel’ovými) oblast’ami turizmu a následnej štrukturálnej zaostalosti periférií (Britton 1982, Nash 1989, Matthews 1978). Podl'a týchto autorov rozvoj turizmu v mladých národných štátoch „tretieho sveta“ ako inherentne top-down proces nezodpovedal záujmom ich obyvatel'ov ako celku, ale jedine potrebám medzinárodnej a teda i domácej buržoázie (,domorodé spolupracujúce elity“), ktorá turistickú infraštruktúru využíva a profituje $\mathrm{z}$ nej; to súčasne podkopáva krehkú národnú identitu hostitel'ských štátov (Crick 1989: 232-234). Táto literatúra nereflektovala skutočnost', že pravidelný a opakovaný kontakt medzi obyvatel'mi zdrojových a ciel'ových oblastí podporuje vznik takých druhov mobilít a sociálnych vzt’ahov, ktoré transcendujú priestorový dualizmus centra a periférie - napr. MacCannell (1992) hovorí o zvrátení pôvodne dominantných smerov pohybu a výmen vo veku „ex-primitívov“.

Oproti tejto štrukturalistickej tradícii kladie Bianchi (2003: 14) post-kolonialistické, foucaultovsky inšpirované práce, ktoré sa síce vyhýbajú esencializmu, ale trpia iným neduhom - zanedbávajú rozmanité socioekonomické kontexty rozvoja turizmu a príliš „uprednostňujú pochopenie [kultúrnej a identitárnej - pozn. MM] diverzity pred štrukturálnymi nerovnost’ami v rozvojovom procese“. Je evidentné, že sú potrebné hlbšie analýzy takých

6 Jednou z najvplyvnejších teoretizácií príčin turizmu sa stala MacCannellova (1976) interpretácia, podl'a ktorej turizmus predstavuje istú reflexiu hodnôt a štruktúry modernej spoločnosti. Procesy urbanizácie a špecializácie vedú k čoraz silnejším pocitom alienizácie, fragmentácie a povrchnej skúsenosti príslušníkov moderných spoločností, pre ktorých turistická spotreba predstavuje hl'adanie stratenej pre-modernej autenticity. Podl'a MacCannella turisti veria, že nadviazanie kontaktu s autentickým Druhým im zároveň umožní nadobudnút' pocit uceleného a zmysluplného self. Nash (1981: 467) zdôraznil nutnost’ konceptualizácie turizmu ako „superštrukturálnej manifestácie nejakej viac základnej reality [o ktorej] je možné uvažovat' ako o obdarenej schopnost'ou spätne ovplyvňovat' realitu, ktorá ju vytvorila“. Podobne aj výber „satelitov“ (čiže destinácií) a vzt’ahov s nimi je možné nahliadat' ako pokusy o vytvorenie superštrukturálnych manifestácií zdrojovej („,metropolitnej“) spoločnosti, ktoré v extrémnych polohách nadobúdajú polohu „turistického imperializmu“. 
ekonomických aspektov, ako je vplyv námezdnej práce na predchádzajúce spôsoby subsistencie či vzt’ah medzi príležitost’ami prinesenými turizmom a majetkovou stratifikáciou miestnych skupín, a to s vyššou vnímavost'ou voči emickej perspektíve (Stronza 2001: 268269).

Jedno zo spojív medzi výskumom transnacionalizmu a turizmu predstavuje teoretické prehodnocovanie vzt'ahov týchto konceptov k produkcii a spotrebe miest, ktoré v oboch prípadoch pracuje s dialektickým chápaním vzt'ahu globálneho a lokálneho aspektu a s predstavou identity miesta ako prekryvu ,imaginárnych svetov“ zakúšaných a vytváraných l’udským konaním. Istým odrazom metafory „tokov“ vo vedeckom diskurze o globalizácii je potom teoretizácia turizmu ako súboru „mobilít“", ktoré určujú, kde a ako bude turizmus performovaný, kde vzniknú a zaniknú jeho lokality, pričom tieto prúdenia sú zároveň na lokalitách, na ktorých „dosadajú“ a ktoré premieňajú, samy vystavené účinkom „glokalizácie“ (Sheller a Urry 2004: 1-2). Turistami vyhl'adávané oblasti pripomínajú kultúrne vysoko globalizované „Svetové mestá“ (Sassen 2001) v tom zmysle, že takisto predstavujú určité nódy či uzly transnacionálnych sietí a tokov, v ktorých sa stretávajú a interagujú migranti, turisti, vysokokvalifikované kozmopolitné elity a rezidenti. V analýze rozvojovej turistickej politiky v Singapure Yeohová a Chang (2001) ukazujú, že turisti sú skutočne jednou z kategórií l'udí, ktorí mestám dodávajú ich globálny charakter a súčasne sú ním prit’ahovaní.

Okrem kultúrneho kontextu turizmus transformuje i materialitu „skutočných“ miest, aj ked’ tieto zásahy sú zvyčajne obmedzené „len“ na vybudovanie potrebnej ubytovacej a pridruženej infraštruktúry - samotný priestor, rovnako ako skúsenost’ pohybu v ňom, sa totiž stáva nielen predmetom produkcie, ale hlavne spotreby (Bianchi 2003: 19). Preto sa „komoditou“, ktorú turisti v istom zmysle konzumujú pricestovaním do nej, stávajú najmä miesta vyznačujúce sa prírodnou krásou, kultúrnou odlišnost'ou a príhodnou klímou, často vzdialené a t’ažšie dostupné. Na druhej strane turizmus podnecuje aj vznik virtuálnych realít a hyperreálnych fantazmagórií s malým alebo žiadnym vzt’ahom k svojmu fyzickému prostrediu, akými sú napr. už spomínané tematické parky. Všetky tieto druhy „,miest na hranie“ (places to play) ale musia byt' opakovane konštruované určitými mobilitnými systémami, viacerými siet’ovo prepojenými mobilitami kapitálu, osôb, predmetov, znakov a informácií, a takisto vhodnými performanciami na strane turistov aj miestnych obyvatel'ov. „Miesta na hranie sú teda často pre vlády, korporácie, miestnych, migrantov a mimovládne organizácie smrtel'ne vážne, pretože sú neprestajne $v$ hre (in play) vo vzt’ahu k viacerým pretínajúcim sa a nepredvídatel'ným mobilitám..." (Sheller a Urry 2004: 6-10). Táto konceptualizácia pomáha neprepadnút' lákavému dojmu, že turizmus je synonymom cestovania zámožných obyvatel'ov vyspelých štátov, umožneného odtelesnenými technológiami a infraštruktúrami; napr. Shellerová (2004) ilustruje s odkazom na existenciu mzdovo nenáročných centier na spracovanie dát v turisticky atraktívnom Karibiku, akými sú Jamaica Digiport International či Barbados Data Processing Centre, že hra jedných si vyžaduje telesnú prácu iných, spätú s konkrétnymi miestami a regulovanú súborom lokálnych politických, ekonomických, sociálnych a kultúrnych praktík. 


\section{Turizmus a transnacionálne identity}

Tak ako je identita prominentnou témou transnacionálnej antropológie, predstavuje súčasne významnú oblast' záujmu i v turistických štúdiách - a to do tej miery, že je možné konštatovat', že „téma identity je v diskurze o turizme všadeprítomná“ (Lanfant 1995: 30). Istý dlh voči turizmu ako takému zo strany transnacionálnej antropológie sa ale dá konštatovat' aj vo vzt'ahu k jeho identitárnemu rozmeru. Binderová (2004: 4, dôraz pridaný autorom) pritom upozorňuje hned' na tri aspekty, ktorými môže začlenenie témy turizmu obohatit' uvažovanie o transnacionalizme: „Na rozdiel od migrácie, turizmus nie je založený na potrebe prežitia, ale má charakter seba-obohatenia a pôžitku. (...) Ďalej obracia náš pohl'ad na skutočnost', že transnacionálna identita $v$ kontexte turizmu môže byt' vytvorená len dokumentovaním prekračovania hraníc. (...) Po tretie, výskum turizmu sa zameriava na účast' jedinca v procese globalizácie bez explicitných politických, ekonomických, či sociálnych ambícií (...) ukazuje, ako sú turistické skúsenosti v podobe transnacionálnych praktík na základe toho, že umožňujú získat' či udržat' si pozíciu vít’aza globalizácie, premieňané na individuálny prospech v globalizovanom svete.“ Zdá sa, že samotnou svojou povahou turizmus obracia našu pozornost' na inštrumentalistický aspekt transnacionálnych identitárnych procesov.

Môžeme pritom rozlišsit' viacero významov a kontextov, v ktorých sú identita a príbuzné koncepty v turistických štúdiách uplatnitel’né. Predovšetkým sa v súlade s neustálou recipročnou a vzájomne konštitutívnou interakciou medzi priestorom a spoločnost'ou (konkrétnejšie medzi miestami/tokmi a komunitami/siet’ami) v globalizovanom svete dajú identifikovat' dva funkčné aspekty turizmu: vystupuje jednak ako faktor vzniku transnacionálnych identít a jednak ako transnacionálne médium vzniku lokalizovaných identít. Neznamená to nutne, že umožňuje vznik dvoch odlišných a jasne oddelených súborov identít; naopak, je opodstatnené predpokladat', že v mnohých inštanciách tieto dva aspekty predstavujú len rôzne fázy konštrukcie jedinej identity (cf. nižšie príklad de-teritorializácie identity počas cesty a jej re-teritorializácie po návrate domov u batôžkárov). Zatial' čo v prvom prípade je identita inherentne spojená s mobilitou jedincov a skupín, ktorí ju konštruujú a performujú (čiže primárne turistov samotných, ale tiež rôznych typov migrantov), $v$ druhom prípade to môže byt' i mobilita Iných, ktorá postačí na podnietenie (často intencionálnej a reflektovanej) práce s vlastnou identitou, inscenovanej v sociálnom, kultúrnom a politickom kontexte danej translokality.

Z Desforgesovej analýzy (2000: 930, pôvodný dôraz) d'alej vyplýva, že koncepty osobnosti vnášané do výskumu turizmu zdiel'ajú viacero podobností, najmä vedomie dôležitosti toho, ako si l'udia predstavujú sami seba a kým by sa chceli stat' (,vnútorný naratív osobnosti“), a možnost' interpretácie turistickej spotreby pomocou týchto predstáv (,vonkajšie skúsenosti a praktiky, ktoré vytvárajú a sú vytvárané týmito historicky a geograficky situovanými významami seba-identity"). Súčasne ale Desforges, ktorého zaujíma vysvetlenie „geografií turistickej spotreby“ $v$ prípade ciest na vel'ké vzdialenosti, načrtáva hned' dve diferencujúce osy: na prvej, týkajúcej sa škály sociálnych interakcií, na ktorých je osobnost’ rozvíjaná, odlišuje medzi sociologizujúcim a kolektivistickým poňatím (gravituje skôr k pojmu identity) a psychologizujúcim a individualistickým poňatím (pojem self). Vo vzt’ahu k možnému využitiu osobnosti $\mathrm{v}$ analýze turizmu potom rozoznáva na jednej strane prístup zameraný na skúsenost' sveta vytváranú turizmom a na druhej strane orientáciu na turistické praktiky a reprezentácie ako symboly sociálnej odlišnosti. 
Čo sa týka konštrukcie identity alternatívnych turistov, ako plodnejšia sa javí druhá z možností, ktorá evokuje tradíciu skúmania „kultúrneho kapitálu“ založenú Bourdieuovou (1984) teóriou dištinkcie a zjemneného vkusu a ústiacu napríklad do Ericksonovej (1996) reformulácie, podla ktorej kapitál adaptovaný na dnešné podmienky je skôr „multikultúrny“ či kultúrne „všežravý““ a zahŕňa znalost' širokej škály menej striktne hierarchizovaných variet a štýlov; túto charakteristiku vykazujú aj niektoré typy alternatívneho turizmu. Význam prvého Desforgesovho rozdelenia značne znižuje rozpoznanie skutočnosti, že v zásade tú istú „interne-externú dialektiku identifikácie môžeme vidiet' účinkovat' v konštrukcii kolektívnych rovnako ako individuálnych sociálnych identít“ (Jenkins 1996: 87), pričom význam pripisovania a performovania odlišnosti $v$ sociálnych interakciách pre utváranie osobnosti čoraz viac prijíma aj súdobá psychológia. Aj ked’ teda konštrukcia identity turistov, najmä batôžkárov, prebieha predovšetkým na individuálnej úrovni, je inherentne spojená so sociálnym kontextom, ktorý jej dodáva surový semiotický „materiál“ a v ktorom sama nadobúda význam; preto sa nezdá dôležité situovat’ načrtávaný výskumný smer na tejto osi.

\section{Turistické etnicity}

Téma identity je $\mathrm{v}$ turistických štúdiách pravdepodobne najrozvinutejšia $\mathrm{v}$ skúmaní „turistickej etnicity“ či turizmu ako „etnických vzt’ahov“. Pierre van den Berghe (1980) ako jeden z prvých upozornil na to, že turizmus predstavuje sám o sebe súbor etnických vzt’ahov a významný prostriedok masového, mocensky a ekonomicky asymetrického interetnického kontaktu, organizovaného podl'a socioekonomickej stratifikácie a etnických hraníc medzi turistami, tourees (čiže objektmi turistického záujmu) a sprostredkovatel'mi, ktorí facilitujú kontakt medzi prvými dvomi skupinami. Turizmus môže v rámci hostitel'skej populácie podnietit' etnickú del'bu práce založenú na predchádzajúcich etnických hierarchiách, na ktoré je aplikovaný (napr. vzt’ahy medzi indiánmi a mesticmi v Peru), pričom ich môže posilnit' či modifikovat'. Van den Berghe d'alej v tematickom čísle Annals of Tourism Research editovanom spolu s Keyesom (1984) poukázal na to, že turizmus môže viest' i k upevneniu etnických stereotypov. Jeho práce však boli napadnuté kvôli esencialistickému poňatiu etnicity (napr. Hitchcock 1999: 19) a zjavná je tiež ich závislost' na prísnom funkčnom rozdelení aktérov „turistického stretnutia“, podl'a ktorého turisti predstavujú vo vzt’ahu k miestnym jednoznačne cudzí, vonkajší prvok.

Pochopitel’nou slabinou mnohých analýz vychádzajúcich z týchto základných predpokladov bol jednostranný pohl'ad na fungovanie moci v interakciách ovplyvňujúcich identitu aktérov. Väčšina autorov tak zdôrazňovala len to, že „turistický pohl'ad“ komunikuje miestnym stereotypné či orientalistické predstavy o tom, akí by podl'a očakávaní mali byt' a správat'sa, a vzhl'adom na nerovné mocenské pozície turistov a tourees tým identitu druhej skupiny naozaj formuje. Autori pritom odkazovali na rôzne determinanty turistickej etnicity: masmédiá (Urry 1990), mladé štáty snažiace sa budovat’ jedinečnú národnú identitu pomocou axiologicky, estetizovane vymedzenej „kultúry“ (Wood 1997), anachronické či bezčasové predstavy o tom, akí by „domorodci“ mali byt', často väziace v koloniálnej minulosti (Cohen 1993), alebo jednoducho marketing cestovných agentúr. Pohlad cudzinca tu vystupuje ako určitý referenčný bod a garant kultúrnej identity, ktorá je na ňom závislá; moc určit', čo je 
a čo nie je autentické, je $\mathrm{v}$ centre, a periféria sa tomu nanajvýš prispôsobuje (Lanfant 1995: 36). Miestni obyvatelia tak spolupracujú na zvláštnom druhu exploitatívnych kapitalistických vzt'ahov: na svojom vlastnom „vykorist'ovatel'skom symbolickom útlaku“, ktorý spočíva v „bytí samým sebou pre iných“ (Bianchi 2003: 19), inými slovami v komodifikácii kultúry a tým i na nej viazanej identity.

Je možné identifikovat' dve základné skupiny dôvodov, prečo je táto argumentácia nahliadaná ako neuspokojivá: empirickú neúplnost' a konceptuálnu problematickost'. Čo sa týka empirických medzier, autori mali tendenciu predpokladat', že na rozdiel od príslubov reklám propagujúcich etnický či kultúrny turizmus je „,v turistickom stretnutí self turistu zmenené len vel’mi málo, zatial' čo self domorodca zaživa zásadnú zmenu“ (Bruner 1991: 248), a na základe toho sa sústredili len na identitárne procesy u miestnych. A práve v spôsobe, ako tieto procesy antropológovia väčšinou rámcovali, nachádzame jednu z pravdepodobných príčin ich dlho pretrvávajúceho nezáujmu o turizmus: „Antropológovia ako intelektuáli pohŕdali turizmom ako komerčným, neautentickým a nevkusným. Mali pocit, že turistická kultúra je jednoducho len oklieštená verzia úplnejšej a autentickejšej domorodej kultúry, ktorá sa nachádza niekde inde“ (Bruner 1996: 159). Morálny podtón tohto diskurzu je teda evidentný - turizmus prispieva k „,bastardizácii“ až zániku domorodej kultúry ako žijúceho, unikátneho systému, zbavuje ju jej pôvodnej hodnoty a funkcie pre jej samotných príslušníkov a mení ju na významovo vyprázdnený tovar. Taká je v skratke argumentácia Greenwoodovej klasickej štúdie (1989) sviatku alarde v baskickom meste Fuenterrabia - jeho sprístupnenie turistom ho údajne pripravilo o všetok žijúci symbolický a kultúrny význam. V podobnom duchu glosuje vplyv turizmu na údajne pôvodné, čisté a neskazené domorodé kultúrne systémy vel'ké množstvo d’alších prác, prestúpených oným kultivovaným pohŕdaním cestovaním a cestovatel'mi, ktoré v úvode svojich Smutných trópov tak pregnantne a bezprostredne vyjadril Lévi-Strauss (1966: 10-11).

Iní autori upozornili, že následkom dominancie tohto poňatia bol vzt’ah kultúry a identity vnímaný lineárne a jednosmerne (rozkladom či premenou kultúry dochádza k rozkladu identity, ktorú plne determinuje) a prehliadala sa možnost' vedomého strategického konania a/alebo kreatívnej rekonštrukcie etnicity domorodcov v reakcii na príležitost' predstavovanú záujmom turistov. Inými slovami, kultúrna zmena môže byt' nielen príčinou, ale i prostriedkom či produktom transformácie identity, a identitárne prejavy (vrátane tých odkazujúcich na primordialistické predstavy o etnicite a kultúre) si môžu miestni osvojit' celkom vedome, a to nielen s ciel'om maximalizovat' zisk, ale aj obnovit' a rozvinút' „svoju“ kultúru spôsobom, ktorý nahliadajú ako pozitívny. Napríklad Chambriovia z Papuy-Novej Guiney pri iniciáciách mladých mužov vyslovujú ako jednu z výziev: „Si dost' (mužom) na to, aby si vyrábal rezby a umiestňoval ich v mužskom dome, kde si ich môžu kúpit' turisti?"“ Chambriovia neinterpretujú príchody turistov do svojich sídel či dokonca ich účast' na iniciačných rituáloch ako znak premeny vedenia zdedeného od predkov, ale naopak ako dôkaz jeho pretrvania a sily - to ono turistov pritahuje a podnecuje, aby si kúpili artefakty (Gewertz a Errington 1991). Podobné reakcie boli opakovane rozoznané i v súvislosti s balijskou kultúrou. Koloniálne holandské úrady otvorili Bali pre turistov už v prvej dekáde 20. storočia (Hitchcock 1998: 125) a rozvoj kultúrneho turizmu neskôr cielene podporovala aj provinčná balijská vláda. „Kultúrna renesancia“ tradičných balijských umeleckých foriem viedla v 70. rokoch amerického 
antropológa McKeana (1973) k formulovaniu tézy „kultúrneho umocnenia“ (cultural involution). Podla neho Balijci svoju kultúru neopustili, ale pridali k tradičným roliam nové, spočívajúce $\mathrm{v}$ performanciách pre turistov, a medzi týmito dvomi oblast’ami kultúry stanovili a udržovali jasné hranice; zároveň im zisky z turizmu umožnili d’alej rozvíjat' tradičnú kultúru. MacCannell (1976) v tejto súvislosti hovoril o rozdelení kultúry v reakcii na turizmus na tzv. frontstage čast', kde domorodci predvádzajú turistom určitý obmedzený okruh aktivít, a backstage, ktorý je chránený pred komodifikáciou. Dnes sa však zdá, že tieto predstavy pramenili skôr z kategórií vlastných antropológom (napr. „profánne“ a „posvätné“), ktoré natívni obyvatelia nemuseli nevyhnutne zdiel'at'. Picard $(1990,1995)$ ukázal, že turizmus nie je možné považovat' vo vzt'ahu k balijskej kultúre za externý - naopak, je jej integrálnou súčast’ou a medzi jednotlivými predpokladanými sférami kultúry, ktoré sú antropológovia (a d’alší aktéri zainteresovaní na takomto rozlišovaní s ciel’om zachovat' kultúrnu „,̌istotu“, napr. provinčná vláda) v pokušení vymedzovat', dochádza k čulej výmene a migrácii prvkov. Nejasnost' deliacej línie medzi kultúrou ako hodnotou samou o sebe a tovarom určeným pre turistický trh, ktorá zodpovedá nejasnosti hranice medzi lokálnym a globálnym na Bali ako turistickej translokalite, nás vedie k záveru, že „doktrína ,kultúrneho turizmu“ (pariwisata budaya) mení balijskú kultúru na to, čo by bolo možné nazvat' ,turistickou kultúrou‘ (budaya pariwisata) - teda na kultúru, ktorú podl'a Balijcov samotných charakterizuje zamieňanie hodnôt kultúry a hodnôt turizmu - a to je presne to, čomu sa táto doktrína pôvodne snažila za každú cenu vyhnút"“ (Picard 1990: 74).

Takéto príklady ukazujú, že domorodci sa môžu k turizmu vzt'ahovat' spôsobmi, ktoré sa podstatne líšia od očakávaní antropológov, a že v niektorých prípadoch nie je vhodné hovorit' o dopadoch turizmu na kultúru a identitu, ale o ich vzájomnom vnútornom formovaní sa. To však samo o sebe nestačí na dekonštrukciu neudržatel'ného konceptuálneho predpokladu tak teórie kultúrneho zániku, ako aj kultúrneho umocnenia - protikladu autentickej a falošnej kultúry a identity. Táto dichotómia podla Shepherda (2002) spočíva nedostatočne doceneným spôsobom na Marxovej teórii hodnoty, konkrétne jeho rozlíšeniu úžitkovej a výmennej hodnoty komodity. Zatial' čo úžitková hodnota je definovaná ako v podstate pravá, autentická, racionálna a prirodzená, výmenná hodnota je falošná, umelá, iracionálna a tým, že prekrýva spoločenskú hodnotu práce, prispieva k odcudzeniu pracovníkov od produktov ich práce. Analogicky antropológovia hodnotia ako neželatel'né následky prisúdenia výmennej hodnoty prvkom kultúry, ale tu si je treba uvedomit', že sociálne „následky sa stávajú problémami, len ked” sú tak definované, a to vedie k otázke, kto ich takto definuje“ (ibid.: 188). Je možné vymedzit' súbor znakov, ktoré pre proponentov týchto postojov odlišujú autentickú, pravú a „posvätnú“ kultúru od tej neautentickej a „profánnej“: je reprodukovaná na špecifickom mieste, špecifickým typom l’udí a pre špecifický účel, ktorý nie je ekonomicky motivovaný (ibid.: 190-192). Vidíme zjavnú podobnost' s l'udovým modelom „etnickej kultúry“ alebo tiež $\mathrm{s}$,redukcionistickou sociológiou kultúry“ odvodenou od herderiánskeho poňatia kultúry ako vyjadrenia jedinečnosti každej l'udskej skupiny, ktorá neproblematicky „vlastní“ túto jedinú, homogénnu (smerom do vnútra „rovnakú“) kultúru, a zároveň ako reifikovaného objektu, ktorý je možné l'ahko a jednoznačne ohraničit' (smerom navonok je „odlišný“") (Benhabib 2002). Je koniec koncov nanajvýš paradoxné, že sú antropológovia ochotní s plnou vážnost'ou uplatňovat' ako analytický koncept to, čo je predmetom túžby samotných etnických 
turistov. Vhodnou alternatívou k deleniu objektov a praktík na komodity a ne-komodity, v ktorom význam oboch strán dichotómie závisí na svojom protiklade, je akceptovanie skutočnosti, že sú všetky objekty a skúsenosti potenciálnymi komoditami: „Je potrebné hovorit’ o súperiacich autenticitách, všetko produktoch konkrétnych spoločenských síl zapojených do procesu kultúrneho (znovu-)vynachádzania a spotreby v kontexte jestvujúcich spoločenských vztahov" (Shepherd 2002: 196).

Komodifikácia kultúry si ako sociálny fakt teda zaslúži náležitú pozornost', ale je nutné opustit' moralizmus a nekriticky prijímané implicitné predpoklady diskurzu o nej. Turizmus môže ovplyvnit', ktoré etnické markers budú preferované ako komodity a súčasne symboly hrdého stotožnenia sa so svojou identitou, a to práve vd’aka tomu, že podporuje vznik vedomia ich výmennej hodnoty; táto reflexívna a transparentná povaha konštrukcie turistickej etnicity býva zdôrazňovaná ako jej charakteristický rys (Wood 1998: 225-226). Napríklad revitalizáciu mayskej identity v Belize na základe štúdia odborných a iných písomných prameňov o kultúre predkov, s ktorou už nie je zachovaný bezprostredný kontakt, popisuje Medinová (2003: 354, pôvodný dôraz) ako príklad „komodifikácie kultúry pre turizmus, ktorá môže zahrňovat' použitie nových pristupových ciest $\mathrm{k}$ velmi starým kultúrnym tradíciám.“ Bruner (1996: 258) v súvislosti s balijskou „turistickou kultúrou“ namiesto rozdelenia kultúry na frontstage a backstage navrhuje predstavu „turistickej hraničnej zóny“ (tourist borderzone) ako prázdneho javiska, na ktoré s rôznymi ciel'mi v čase performancií prichádzajú (viac-menej tí istí) miestni obyvatelia a (neustále sa meniaci) turisti. Kultúrne formy $\mathrm{v}$ tomto transnacionálnom priestore vznikajú $\mathrm{v}$ neustálej interakcii a výmene turistov, Balijcov, migrantov zamestnaných v kultúrno-turistickom komplexe a zaangažovaných subjektov (napr. centrálnej a provinčnej vlády, súkromných firiem), pričom niektoré z týchto foriem sa po čase stávajú organickou súčast’ou každodennej kultúrnej praxe miestnych (cf. tiež koncept „vznikajúcej autenticity“ in Cohen 1988: 380). Hraničná zóna teda nie je fluidným, dokonale synkretickým a „bezšvovým“ priestorom, ale miestom produkcie odlišností a politických zápasov o ich konkrétne podoby.

Ideu turistickej translokality je d’alej možné rozviest' konštatovaním, že súbor inside/ outside percepcií a praktík a na ne nadväzujúca manipulácia identity nevyžadujú ako spúšt’ač prítomnost' cudzincov-turistov. Odhaduje sa, že štyria z piatich turistov sú občania štátu, v ktorom cestujú (Heath a Wall 1992: 3), a vd’aka tranzitivite turistického statusu sa teda napríklad Indonézan, inak vystavený „turistickému pohl’adu“ medzinárodných cestovatel’ov, môže vo svojom vlastnom štáte na istý čas stat’ tým, kto sa takto pozerá na Iných, ktorí sú zároveň na iných úrovniach a škálach klasifikácie jeho „blízkymi“. Etnické vzt’ahy a identita miestnych býva tiež významne ovplyvňovaná prítomnostou migrantov pracujúcich v turistickom sektore, literatúrou často prehliadaných. Spôsoby zamestnávania a postoje k prevažne rumunským a ruským pracovným migrantkám v Severocyperskej tureckej republike tak odrážajú sociálne zápasy obklopujúce konštrukciu ženského rodu v meniacej sa miestnej spoločnosti (Scott 1995). Transnacionálna sociálna forma podnietená turizmom v takýchto prípadoch vynáša na povrch lokálne identitárne napätia a potenciálne ul'ahčuje ich vyriešenie, všeobecne povedané, ,pokial' sa tvrdí, že turizmus podporuje vynachádzanie, obnovovanie a rušenie odlišnosti, ide o zdôrazňovanie prechodných priestorov v kultúrnych praktikách“ (Bianchi 2003: 17). Príchod migrantov z rôznych častí Kene do turistami vyhl'adávaného 
prímorského regiónu Malindi a súbor s turizmom súvisiacich ekonomických aktivít a vzt’ahov vyvolal etnické napätie a konflikt, ktorý na jednej strane posilnil vnútornú kohéziu predtým vysoko štiepnych etnických skupín a na druhej strane viedol k vzniku interetnických identít jednotlivcov s podobnými záujmami, ako ukazuje napr. solidárne správanie medzi prostitútkami malaya (Jamison 1999).

\section{Batôžkárske identity}

Kým vo vzt’ahu k turistickým etnicitám a d’alším uvedeným prípadom zohráva turizmus rolu určitého transnacionálneho kontextu či podnetu pre formáciu lokalizovanej identity, turistom samotným primárne umožňuje vznik ich deteritorializovanej a prechodnej identity, ktorej význam môžu až následne vyjednávat' a situovat' v lokálnom sociálnom a diskurzívnom rámci (najčastejšie po návrate „domov“). Na úrovni externej sociálnej klasifikácie zo strany tourees, s ktorou sa turisti nemusia stotožňovat' a ktorej si ani nemusia byt' vedomí, pozorujeme predovšetkým ich zarad’ovanie do jednotnej supra-etnickej či transnacionálnej kategórie na základe vnímanej podobnosti ich aktuálnej situácie, správania, ale tiež ekonomického statusu či fyziognómie. Napríklad v seychelskej kreolčine založenej na francúzštine je výraz tourist hravo pozmenený na ironické tout riche („každý bohatý“), zatial' čo v indonézskej Jogjakarte budú ako turis s vel'kou pravdepodobnost'ou identifikovaní všetci belošsky vyzerajúci cudzinci bez ohl'adu na skutočný dôvod ich pobytu (Hitchcock 1999: 25). Seba-identifikácia turistov, čiže ich prijatie a internalizácia špecifickej identity, je potom nesená v prvom rade stretnutím s Iným, pričom predstava turistov o tom, kým tento Iný je, je ovel'a rozmanitejšia, než majú mnohí sociálni vedci tendenciu predpokladat'. „Tradiční“ masoví turisti tak môžu byt' celkom spokojní so zachovaním a potvrdením starých známych stereotypov o exotických, primordiálnych a nezmenených domorodcoch. Skupina turistov na Bali, ktorých sa Bruner (1996: 175) v dvojitej úlohe antropológa a ich sprievodcu-experta pýtal na dojmy z tanečných predstavení, celkom otvorene priznávala, že ich nezaujíma otázka „autenticity“, ale skôr estetických štandardov vystúpení. Pre turistov, ktorí svoju turistickú identitu reflektujú a vedome sa s ňou pohrávajú namiesto toho, aby sa od nej snažili dištancovat', sa vžilo označenie post-turista (napr. Urry 1990: 91).

Naopak „alternatívni“ turisti prezentujú ako ciel’ svojich ciest dosiahnutie ,autentických“ zážitkov a skúseností, hlbokého, ,skutočného“ pochopenia a (dočasného) začlenenia sa medzi Iných, čoho očakávaným následkom býva i vlastná premena smerom „k lepšiemu“. Za akýchsi predchodcov dnešných batôžkárov bývajú pokladaní „nomádi“ či drifters vychádzajúci z hippie hnutia 60. a 70. rokov. Títo zvyčajne vzdelaní mladí príslušníci strednej triedy sa vyhýbali infraštruktúre masového turizmu, pohybovali sa rozptýlene medzi miestnymi populáciami a dlhodobým cestovaním sa snažili uniknút' normatívnym životným dráham. Ani ich praktikám sa však nevyhla pomerne rýchla inštitucionalizácia, ktorá spolu s rastúcim počtom drifters viedla k častejším interakciám medzi nimi navzájom než s príslušníkmi host'ovských spoločností (Cohen 1972, 1973), napríklad v komunitách založených v indickej Goe. Preto neprekvapuje, že rôzne druhy alternatívnych turistov, ktorí sa aspoň rétoricky hlásia k podobným hodnotám, sú častým terčom normatívne ladených akademických kritík. Napr. pre Munta (1994) sú ekoturisti skôr ,egoturistami“, ktorí fetišizujú a estetizujú rozvojové krajiny 
a snažia sa ich návštevami, chápanými ako prejavy vhodného životného štýlu, získat' kultúrny kapitál, potrebný na konštrukciu identít príslušníkov „nových“ stredných tried.

Nielenže sa ich skutočná prax často líši od deklarovaných ideálov, ale batôžkári sú natol'ko heterogénni čo do pôvodu, rodu, socioekonomického statusu, dížky a spôsobu cesty, destinácie, rozpočtu a všemožných d'alších charakteristík, že sa zdá otázne, či ich má vôbec zmysel vymedzovat' ako skupinu, a ak áno, tak akým spôsobom (viz tiež odchylnost' od klasických antropologických vymedzení skupiny vyššie). Sørensen (2003) preto považuje za zmysluplnejšie skúmat' batôžkárov skôr vo význame sociálne konštruovanej kategórie než deskriptívneho pojmu a potvrdzuje, že aj tí z nich, ktorí túto nálepku odmietajú, sa $\mathrm{k}$ nej nejakým spôsobom vzt’ahujú: „Explicitné či implicitné rozoznanie týchto pojmov je dôležité spôsobom, ktorý siaha za implicitné dištancovanie sa od stereotypu turistu. Títo jedinci sa totiž v rôznej miere a intenzite vzt’ahujú $\mathrm{k}$ zdiel'anému referenčnému rámcu (...) a ich čiastková a zlomkovitá interakcia vytvára význam, ktorý ovplyvňuje normy, hodnoty, správanie a d'alšie prvky ich sociálnej existencie“ (ibid.: 848-849).

Ďalším bodom, ktorý umožňuje uchopit’ tento druh turistov ako identitárnu skupinu, sú ich intenzívne sociálne interakcie počas cesty, rýchlo nadväzované a prerušované vzt’ahy a komunikácia, v ktorej cestovanie vystupuje ako primárna a automaticky predpokladaná téma, ale ktorá môže pomerne l'ahko prejst' aj do sfér inak vnímaných ako značne intímne; vel'mi intenzívne a súčasne extenzívne komunikačné siete batôžkárov si všíma už i staršia literatúra (napr. Riley 1988). Interakcia a komunikácia v rámci skupiny dokonca figurujú medzi často uvádzanými motívmi nezávislého cestovania a vzhl'adom na to, že sú tieto javy $\mathrm{v}$ prípade batôžkárov nápadnejšie než u turistov všeobecne, predstavujú vhodný predmet pre modelové štúdie, ktorých výsledky môžu potom byt' vztiahnuté i k turistom ako takým (Murphy 2001). Toto správanie pritom kontrastuje so seba-percepciou batôžkárov ako určitých kultúrnych mediátorov, ktorí počas ciest zbierajú zážitky a vnemy v kontakte s d'alšími cestovatel'mi a domorodými Inými a následne ich sprostredkúvajú svojej rodine, priatel'om, kolegom atd'. Intenzita interakcií a komunikácie medzi neustále sa obmieňajúcimi, často do istej miery anonymnými aktérmi nahrádza rolu transgeneračnej reprodukcie a trvalých sociálnych inštitúcií pri odovzdávaní noriem, hodnôt a spôsobov správania, vd'aka čomu sú tieto prvky málo rigidné, neustále ad hoc vyjednávané, manipulované a prispôsobované (Sørensen 2003: 855). Všeobecná fludita a mobilita batôžkárskej identity korešponduje s klúúcovou úlohou internetu pri jej udržovaní po návrate „domov“; navyše jeho používanie počas cesty na kontaktovanie iných cestovatel'ov, ktorí sa takisto nachádzajú niekde v teréne, a na komunikáciu s rodinou, priatel'mi či spolupracovníkmi „doma“, umožňuje byt' do istej miery vo viacerých časopriestoroch súčasne a stierat’ hranice medzi nimi.

Autori sa pochopitel'ne vo vzt'ahu k batôžkárom zaoberali otázkami získavania oceňovaných kultúrnych zdrojov, ktoré spájali so strategickým správaním príslušníkov vzdelanej strednej triedy. Binderová (2004: 5) hovorí o neustále obnovovanej a redefinovanej transnacionálnej identite, ktorá odkazuje na svet rovnako ako na jednotlivca a ktorú nazýva globedentity: „V nadväznosti na diskurzy globalizácie v hospodárstve, vzdelávaní a sociálnych a kultúrnych vedách sú to predovšetkým prvky telesnej mobility a face-to-face interakcií, ktoré vystupujú do popredia ako predpoklady pre identitu spíňajúcu požiadavky globalizujúcich sa spoločností. Nielenže globálni hráči očakávajú, že ich zamestnanci budú flexibilní a mobilní 
a že budú ovládat' rôzne jazyky, ale už od raného vzdelávania sa žiaci učia, aké dôležité je spoznat' „Iného' prostredníctvom cestovania s otvorenou mysl'ou.“ Nezávislé cestovanie bez ohl'adu na udávané motivácie môže teda rôznym príjemcom signalizovat' samostatnost', čulý záujem o problémy sveta či jednoducho „lepší vkus“, než majú stigmatizovaní masoví turisti. Konštitutívnymi prvkami takejto privilegovanej a privilegujúcej identity sú fyzická mobilita, ktorá umožňuje získat' vyšší spoločenský status; priestor aj s jeho prekračovanými hranicami ako sémantický zdroj skúseností; neustála hra deteritorializácie a reteritorializácie; interakcie medzi cestovatel'mi navzájom a najmä autentifikácia pomocou kontaktov s domorodcami, ktorí sú diskurzívne rámcovaní ako výrazne odlišní, hoci sú typicky vybavení aspoň čiastočnými kompetenciami pre transakcie s príslušníkmi západných spoločností. Desforges (1997), ktorý na základe híbkových rozhovorov s batôžkármi hovorí o „zbieraní miest“ prezentovaných ako séria odlišností od domova, však obracia pozornost’ tiež na to, že vyt’aženie výhodného kultúrneho kapitálu z „autentických“ zážitkov z tretieho sveta (napr. zaradením zmienky o ceste do CV odovzdanom pri pracovnom pohovore) rozhodne nie je čímsi samozrejmým, ked’že rôzne špecifické kontexty lokalizácie môžu predstavovat' náročné výzvy. Ako ukazuje príklad cestovatel'ky, ktorá zistila, že musí svoje cesty rámcovat' vhodným spôsobom, aby nebola potenciálnymi zamestnávatel'mi vnímaná ako nespol’ahlivá fluktuantka, ,imaginatívne geografie cestovatel'ov, alebo tiež to, kde by mali íst' ,zbierat' miesta', sú otvorené pochybnostiam“ (ibid.: 187).

Silnou tendenciou je v súčasnosti skúmanie týchto javov ako diskurzívnej a špecificky naratívnej konštrukcie identity a generovania naratívneho kapitálu. Špecifikami formácie identity prostredníctvom rozprávania príbehov je podla niektorých naratívnych teoretikov jej temporalita, ktorá umožňuje spájaním jednotlivých životných skúseností do časovo súvislých útvarov komunikovat' dojem kohéznej identity. Iní autori tvrdia, že individuálne príbehy bývajú nejakým spôsobom prepojené s „vel'kými“ kultúrnymi príbehmi (master narratives, cultural plotlines a pod.) a vzt’ahujú tak konštruovanú identitu k širším sociálnym a kultúrnym očakávaniam (Benwell a Stokoe 2006: 138-139). To sa prejavuje v prípade „naratívov osobnej premeny“ mladých izraelských batôžkárov - ked’že nezávislé cestovanie je tradičnou doménou západnej mládeže z vyšších vrstiev, takéto príbehy predstavujú pre skúmaných Izraelčanov potvrdenie príslušnosti ku kolektívnej identite, na ktorú sa orientujú (Noy 2004: 82). Tematizácia osobnej premeny prebieha $\mathrm{v}$ dvoch hlavných žánroch naratívov, „,romantickom“ a „nábožnom“, tie ale zdiel’ajú základné charakteristiky: sprostredkúvajú stretnutie $\mathrm{s}$ autenticitou, ktorá je zažitá na exotických, primordiálnych miestach a využitá ako komodita, a rozprávajú o vybočení z hraníc „existenčne známeho“ s ciel’om nájst' „Vznešeného, autentického Druhého“ a vd’aka nemu zakúsit' osobnostnú zmenu (ibid.: 92). Vzt'ah medzi identitou a diskurzom ako sociálne významnou jazykovou praxou teda zjavne tvorí d’alší sl'ubný most medzi spoločensko-vedným výskumom transnacionalizmu a turizmu.

\section{Záver}

Konštrukcia identity a jej vzt’ahy s geografickými a sociálnymi priestormi predstavujú jednu z možných spojníc antropológie transnacionalizmu a turistických štúdí, ktorú som sa tu ako interdisciplinárne pole bádania pokúsil situovat' vo vzt’ahu k jeho zdrojovým 
doménam, otázkam, ktorými by sa malo zaoberat', a konceptom, ktoré pritom môže využit'. Zároveň sa jedná o jedno z najsl'ubnejších z eventuálnych spojení, ked’že tieto témy boli už v obidvoch východzích poliach pomerne dôkladne rozpracované. Množstvo d’alších relevantných predmetov záujmu bolo pochopitel'ne vynechaných, napríklad účast' transnacionálnych korporácií na turistickom priemysle, úloha turizmu ako prostriedku transnacionálne riadeného a plánovaného rozvoja chudobných štátov či klasifikácia určitých budov, sídel a miest všeobecne ako súčastí globálne spravovaného „svetového dedičstva“ (viz proces heritagization in Arellano 2004: 68). Priestor nedovolil adekvátne postihnút' dokonca ani niektoré čiastkové otázky týkajúce sa identity, konkrétne napríklad, aké sú vzt’ahy medzi politikou rozvoja turizmu v rámci EÚ a formáciou vedomia európanstva. Avšak aj tie problémy, ktoré sa tu otvorit' podarilo, odkazujú na klúčové zistenie, že ak chce antropológia a sociálna veda ako taká udržat' krok so stále rastúcim významom transnacionálnych skúseností a praktík pre spôsoby sociálnej klasifikácie a seba-identifikácie, potrebuje sa definitívne odpútat' od sympatií $\mathrm{k}$ bonmotom, podl'a ktorých je napríklad turistický sprievodca nástrojom slepoty (Barthes 1972: 76) - pretože turistický diskurz v skutočnosti funguje ako nástroj videnia, ktorý nám sprostredkúva krajiny, kultúry, identity seba aj Iných (vrátane tých transnacionálnych), a úlohou antropológie je pochopit’ presnú povahu týchto mediácií.

\section{Literatura}

APPADURAI, Arjun. Global ethnoscapes: notes and queries for a transnational anthropology. In FOX, R.G. Recapturing Anthropology: Working in the Present. 1. vyd. Santa Fe: School of American Research Press, 1991, s. 191-210. ISBN 0-93345-278-0.

APPADURAI, Arjun. The production of locality. In FARDON, R. Counterworks: Managing the Diversity of Knowledge. 1. vyd. London: Routledge, 1995, s. 204-225. ISBN 0-41510-793-8.

ARAMBERRI, Julio. The host should get lost. Paradigms in the tourism theory. Annals of Tourism Research, 2001, č. 28, s. 738-761. ISSN 0160-7383.

ARELLANO, Alexandra. Bodies, spirits and Incas: performing Machu Picchu. In SHELLER, M., URRY, J. Tourism Mobillities: Places to Play, Places in Play. 1. vyd. London / New York: Routledge, 2004, s. 67-77. ISBN 0-415-33879-0.

BARTH, Fredrik. Introduction. In BARTH, F. Ethnic Groups and Boundaries. Long Grove: Waveland Press, 1998. s. 9-38. ISBN 0-88133-979-2.

BAUDRILLARD, Jean. Simulacra and Simulation. Ann Arbor: University of Michigan Press, 1995. 164 s. ISBN 0-47206-521-1.

BAUMAN, Zygmut. Myslet sociologicky. 1. vyd. Praha: Sociologické nakladatelství, 1996. 233 s. ISBN 80-85850-14-1.

BAUMAN, Zygmunt. Globalizace: di̊sledky pro člověka. 1. vyd. Praha: Mladá fronta, 1999. 157 s. ISBN 80-204-0817-7.

BAUMAN, Zygmut. Tekutá modernost. 1. vyd. Praha: Mladá fronta, 2002. 343 s. ISBN 80204-0966-1.

BAZIN, Jean. Každému svého Bambaru. Cargo. Časopis pro sociální/kulturni antropologii, 2002, č. 1/2, s. 6-33. ISSN 1212-4923. 
BENHABIB, Sheyla. The Claims of Culture: Equality and Diversity in the Global Era. 1. vyd. Princeton: Priceton University Press. 2002. 216 s. ISBN 0-69104-863-0.

BENWELL, Bethan; STOKOE, Elizabeth. Discourse and Identity. 1. vyd. Edinburgh: Edinburgh University Press. 2006. 328 s. ISBN 0-74861-750-7.

BIANCHI, Raoul V. Migrant tourist-workers: exploring the ,contact zones' of post-industrial tourism. Current Issues in Tourism, 2000, č. 3, s. 107-137. ISSN 1368-3500.

BIANCHI, Raoul V. Place and power in tourism development: tracing the complex articulations of community and locality. PASOS. Revista de Turismo y Patrimonio Cultural, 2003, č. 1, s. 13-32. ISSN 1695-7121.

BINDER, Jana. Travellerscapes. Tourism Research and Transnational Anthropology. University Frankfurt am Main: Research Group Transnationalism Working Paper Number 6. 2004. 13 s.

BOURDIEU, Pierre. Distinction: A Social Critique of the Judgment of Taste. 1. vyd. Cambridge: Harvard University Press. 640 s. ISBN 0-67421-280-0.

BOURDIEU, Pierre. Identity and representation: elements for a critical reflection on the idea of region. In THOMPSON, J. B. Language and Symbolic Power. 1. vyd. (paperback). Cambridge / Malden: Polity Press, 1992, s. 220-228. ISBN 0-7456-1034-X.

BRITTON, Stephen G. The political economy of tourism in the Third World. Annals of Tourism Research, 1982, č. 9, s. 331-358. ISSN 0160-7383.

BRUNER, Edward M. Transformations of the self in tourism. Annals of Tourism Research, 1991, č. 18, s. 238-250. ISSN 0160-7383.

BRUNER, Edward M. Tourism in the Balinese borderzone. In LAVIE, S., SWEDENBURG, T. Displacement, Diaspora, and Geographies of Identity. 1. vyd. Durham: Duke University Press, 1996, s. 157-179. ISBN 0-82231-720-6.

CASTELLS, Manuel. The Rise of the Network Society. The Information Age: Economy, Society and Culture, Vol. I. 1. vyd. Cambridge / Oxford: Blackwell Publishing, 1996. 481 s. ISBN 1-55786-617-1.

CLIFFORD, James. Routes: Travel and Translation in the Late Twentieth Century. 1. vyd. Cambridge: Harvard University Press, 1997. 416 s. ISBN 0-67477-961-4.

COHEN, Erik. Toward a sociology of international tourism. Social Research, 1972, č. 39, s. $164-182$.

COHEN, Erik. Nomads from affluence. Notes on the phenomenon of drifter tourism. International Journal of Comparative Sociology, 1973, č. 14, s. 89-103. ISSN 0020-7152.

COHEN, Erik. Authenticity and commoditization in tourism. Annals of Tourism Research, 1988, č. 15, s. 371-386. ISSN 0160-7383.

COHEN, Erik. The study of touristic images of native people: mitigating the stereotype of a stereotype. In BUTLER, R. W., PEARCE, D. G. Tourism Research: Critiques and Challenges. 1. vyd. London: Routledge, 1993, s. 36-69. ISBN 0-41508-319-2.

CRICK, Malcolm. Representations of international tourism in the social sciences: sun, sex, sights, savings and servility. Annual Review of Anthropology, 1989, č. 18, s. 307-344. ISSN 0084-6570. 
DESFORGES, Luke. ,Checking out the planet'. Global representations/local identities and youth travel. In SKELTON, T., VALENTINE, G. Cool Places: Geographies of Youth Cultures. 1. vyd. London: Routledge, 1997, s. 175-192. ISBN 0-41514-921-5.

DESFORGES, Luke. Traveling the world. Identity and travel biography. Annals of Tourism Research, 2000, č. 27, s. 926-945. ISSN 0160-7383.

DUFFY, Rosaleen. Ecotourists on the beach. In SHELLER, M., URRY, J. Tourism Mobillities: Places to Play, Places in Play. 1. vyd. London / New York: Routledge, 2004, s. 32-43. ISBN 0-415-33879-0.

EBSCOhost. SocINDEX [online]. 2008 [cit. 2008-05-25]. Dostupný na www: http://web. ebscohost.com.

ERICKSON, Bonnie H. Culture, class and connections. American Journal of Sociology, 1996, č. 102, s. 217-251. ISSN 0002-9602.

GEWERTZ, Deborah; ERRINGTON, Frederik. Twisted Histories, Altered Contexts: Representing the Chambri in a World System. 1. vyd. New York: Cambridge University Press, 1991. 278 s. ISBN 0-52139-587-9.

GILLE, Zsuzsa; Ó RIAIN, Seán. Global ethnography. Annual Reviews of Sociology, 2002, č. 28, s. 271 -295. ISSN 0360-0572.

GOTTDIENER, Mark. The Theming of America. 2. vyd. Boulder: Westview Press, 2001. 216 s. ISBN 0-81339-765-0.

GREENWOOD, Davydd J. Culture by the pound: an anthropological perspective on tourism as cultural commoditization. In SMITH, V. Hosts and Guests: The Anthropology of Tourism. 2. vyd. Philadelphia: University of Pennsylvania Press, 1989, s. 171-186. ISBN 0-81221-280-0.

GUPTA, Akhil; FERGUSON, James. Beyond, culture': space, identity and the politics of difference. Cultural Anthropology, 1992, č. 7, s. 6-23. ISSN 0886-7356.

HALL, Stuart. Old and new identities, old and new ethnicities. In KING, A. D. Culture, Globalization and the World-System. 1. vyd. Houndmills: Macmillan, 1991, s. 41-68. ISBN 0-333-53560-X.

HANNERZ, Ulf. Transnational Connections: Culture, People, Places. 1. vyd. London: Routledge, 1996. 212 s. ISBN 0-41514-309-8.

HANNERZ, Ulf. Flows, Boundaries and Hybrids: Keywords in Transnational Anthropology. Oxford: University of Oxford, Working Paper Series in „Transnational Communities“ Programme, 1997. 25 s. [WPTC-2K-02].

HEATH, Ernie; WALL, Geoffrey. Marketing Tourism Destinations: A Strategic Planning Approach. 1. vyd. New York: John Wiley, Sons, 1992. 240 s. ISBN 0-47154-067-6.

HITCHCOCK, Michael. Tourism, Tam An Mini, and national identity. Indonesia and the Malay World, 1998, č. 26, s. 124-135. ISSN 1363-9811.

HITCHCOCK, Michael. Tourism and ethnicity: situational perspectives. International Journal of Tourism Research, 1999, č. 1, s. 17-32. ISSN 1099-2340.

CHORVÁT, Ivan. Turista a turizmus ako metafory pohybu a pohybu človeka v modernej spoločnosti. K niektorým vybraným koncepciám sociológie turizmu. Sociální studia, 2006, č. 1, s. 111-128. ISSN 1214-813X. 
JAMISON, David. Tourism and ethnicity. The brotherhood of coconuts. Annals of Tourism Research, 1999, č. 26, s. 944-967. ISSN 0360-0572.

JENKINS, Richard. Social Identity. 1. vyd. London / New York: Routledge, 1996. 224 s. ISBN 0-41512-053-5.

KEARNEY, Michael. The local and the global: the anthropology of globalization and transnationalism. Annual Review of Anthropology, 1995, č. 24, s. 547-565. ISSN 0084-6570.

KING, Russell. Tourism, labour and international migration. In MONTANARI, A., WILLIAMS, A. M. European Tourism: Regions, Spaces and Restructuring. 1. vyd. Chichester: John Wiley \& Sons Ltd, 1995, s. 177-190. ISBN 0-47195-286-9.

LANFANT, Marie-Françoise. International tourism, internationalization, and the challenge to identity. In LANFANT, M. F., ALLCOCK, J. B., BRUNER, E. M. International Tourism: Identity and Change. 1. vyd. London: Thousand Oaks, 1995, s. 24-43. ISBN 0-80397-513-9.

LÉVI-STRAUSS, Claude. Smutné tropy. 1. vyd. Praha: Odeon, 1966. $300 \mathrm{~s}$.

MacCANNELL, Dean. The Tourist: A New Theory of the Leisure Class. 1. vyd. New York: Macmillan, 1976. 224 s. ISBN 0-33321-183-9.

MacCANNELL, Dean. Empty Meeting Grounds: The Tourist Papers. 1. vyd. London / New York: Routledge, 1992. 360 s. ISBN 0-41505-693-4.

MATHIESON, Alister; WALL, Geoffrey. Tourism. Economic, Physical and Social Impacts. 1. vyd. London: Prentice Hall, 1982. 208 s. ISBN 0-58230-061-4.

MATTHEWS, Harry G. International Tourism: A Political and Social Analysis. 1. vyd. Cambridge: Schenkman, 1978. 100 s. ISBN 0-87073-944-1.

MATTOVÁ, Irina. Globalizácia - prístupy a koncepcie vybraných autorov. Sociálne a politické analýzy, 2007, č. 1, s. 46-72. ISSN 1337-5555.

McKEAN, Phillip. Cultural Involution: Tourists, Balinese, and the Process of Modernization in an Anthropological Perspective. Brown University: PhD dissertation, 1973.

MEDINA, Laurie Kroshus. Commoditizing culture. Tourism and Maya identity. Annals of Tourism Research, 2003, č. 30, s. 353-368. ISSN 0360-0572.

MUNT, Ian. Eco-tourism or ego-tourism? Race and Class, 1994, č. 36, s. 49-60. ISSN 03063968.

MURPHY, Laurie. Exploring social interactions of backpackers. Annals of Tourism Research, 2001, č. 28, s. 50-67. ISSN 0360-0572.

NASH, Dennison. Tourism as an anthropological subject. Current Anthropology, 1981, č. 22, s. 461-468. ISSN 0011-3204.

NASH, Dennison. Tourism as a form of imperialism. In SMITH, V. Hosts and Guests: The Anthropology of Tourism. 2. vyd. Philadelphia: University of Pennsylvania Press, 1989, s. 37-54. ISBN 0-81221-280-0.

NASH, Dennison. Anthropology of Tourism. 1. vyd. Tarrytown: Pergamon, 2001. 240 s. ISBN 0-08042-398-1.

NOY, Chaim. This trip really changed me. Backpackers' narratives of self-change. Annals of Tourism Research, 2004, č. 31, s. 78-102. ISSN 0360-0572.

ORTNER, Sherry B. Theory in anthropology since the sixties. Comparative Studies in Society and History, 1984, č. 26, s. 126-166. ISSN 0010-4175. 
PICARD, Michel: ,Cultural tourism“ in Bali: cultural performances as tourist attraction. Indonesia, 1990, č. 49, s. 37-74.

PICARD, Michel: Cultural heritage and tourist capital in Bali. In LANFANT, M. F., ALLCOCK, J. B., BRUNER, E. M. International Tourism: Identity and Change. 1. vyd. London: Thousand Oaks, 1995, s. 44-66. ISBN 0-80397-513-9.

PORTES, Alejandro; GUARNIZO, Luis E.; LANDOLT, Patricia. The study of transnationalism: pitfalls and promise of an emergent research field. Ethnic and Racial Studies, 1999, č. 22, s. 217-237. ISSN 0141-9870.

PRATT, Mary Louise. Fieldwork in common places. In CLIFFORD, J., MARCUS, G. E. Writing Culture. The Poetics and Politics of Ethnography. 1. vyd. Berkeley / London: University of California Press, 1986, s. 27-50. ISBN 0-520-05729-5.

RILEY, Patricia J. Road culture of international long-term budget travelers. Annals of Tourism Research, 1988, č. 15, s. 313-328. ISSN 0360-0572.

SASSEN, Saskia. The Global City: New York, London, Tokyo. 2. vyd. Princeton: Princeton University Press, 2001. 398 s. ISBN 0-69107-063-6.

SCOTT, Julie. Sexual and national boundaries in tourism. Annals of Tourism Research, 1995, č. 22, s. 385-403. ISSN 0360-0572.

SHELLER, Mimi. Demobilizing and remobilizing Caribbean paradise. In SHELLER, M., URRY, J. Tourism Mobillities: Places to Play, Places in Play. 1. vyd. London / New York: Routledge, 2004, s. 13-21. ISBN 0-415-33879-0.

SHELLER, Mimi; URRY, John. Introduction. In SHELLER, M., URRY, J. Tourism Mobillities: Places to Play, Places in Play. 1. vyd. London / New York: Routledge, 2004, s. 1-10. ISBN 0-415-33879-0.

SHEPHERD, Robert. Commodification, culture and tourism. Tourist Studies, 2002, č. 2, s. 183-201. ISSN 1468-7976.

SMITH, Valene. Hosts and Guests: The Anthropology of Tourism. 2. vyd. Philadelphia: University of Pennsylvania Press, 1989. 352 s. ISBN 0-81221-280-0.

SØRENSEN, Anders. Backpacker ethnography. Annals of Tourism Research, 2003, č. 30, č. 847-867. ISSN 0360-0572.

STRONZA, Amanda. Anthropology of tourism: forging new grounds for ecotourism and other alternatives. Annual Review of Anthropology, 2001, č. 30, s. 261-283. ISSN 0084-6570.

UNWTO (World Tourism Organization). Tourism Highlights 2007 Edition [online]. 2007 [cit. 2008-06-02]. Dostupný na www: http://www.unwto.org.

URRY, John. The Tourist Gaze: Leisure and Travel in Contemporary Societies. 1. vyd. London / Thousand Oaks: Sage, 1990. 200 s. ISBN 0-80398-183-X.

URRY, John. Sociology Beyond Societies: Mobilities for the Twenty-First Century. 1. vyd. London: Routledge, 2000. 248 s. ISBN 0-41519-089-4.

VAN DEN BERGHE, Pierre L. Tourism as ethnic relations: a case study of Cuzco, Peru. Ethnic and Racial Studies, 1980, č. 3, s. 375-392. ISSN 0141-9870.

VAN DEN BERGHE, Pierre L.; KEYES, Charles F. „Tourism and Ethnicity“: Annals of Tourism Research (Special Issue), 1984, č. 11:3. ISSN 0360-0572.

VERTOVEC, Stephen. Conceiving and researching transnationalism. Ethnic and Racial Studies, 1999, č. 22, s. 447-462. ISSN 0141-9870. 
VERTOVEC, Stephen. Transnationalism and identity. Journal of Ethnic and Migration Studies, 2001, č. 27, s. 573-582. ISSN 1369-183X.

WEST, Brad. Consuming national themed environments abroad: Australian working holidaymakers and symbolic national identity in ,Aussie‘ theme pubs. Tourist Studies, 2006, č. 6, s. 139-155. ISSN 1468-7976.

WILlIAMS, Allan M.; HALL, C. Michael. Tourism and Migration: New Relationships between Production and Consumption. 1. vyd. New York: Springer, 2002. 300 s. ISBN 1-40200-454-0.

WOOD, Robert E. Tourism and the state: ethnic options and constructions of otherness. In PICARD, M., WOOD, R. E. Tourism, Ethnicity and the State in Asian and Pacific Societies. 1. vyd. Honolulu: University of Hawaii Press, 1997, s. 1-34. ISBN 0-82481-911-X.

WOOD, Robert E. Touristic ethnicity: a brief itinerary. Ethnic and Racial Studies, 1998, č. 21, s. 218-241. ISSN 0141-9870.

YEOH, Brenda s. A.; CHANG, T. C. Globalising Singapore: debating transnational flows in the city. Urban Studies, 2001, č. 38, s. 1025-1044. ISSN 0042-0980.

\section{Autor}

Marek Mikuš vyštudoval etnológiu na Filozofickej fakulte Univerzity Karlovy v Prahe a momentálne na London School of Economics absolvuje ročný program ,antropológia a rozvoj“ v príprave na doktorandské štúdium. Jeho výskumnými záujmami sú najmä antropológia rozvoja, kolektívne a etnické identity, diskurz a sociálne vylúčenie.

Kontakt:m.mikus@lse.ac.uk 